resting ground of such migrants furnished 40,003 hawks, or 55 per cent of the total kill during that period, and a single hawk-hunter was rewarded in 1930 to the tune of 900 dollars. It was against much opposition that Mr. E. I, Compte, the State game warden, finally succeeded in inducing the legislature to withdraw the bounty.

\section{A Capsid Bug New in Britain}

In the Entomologist's Monthly Magazine for August 1932 Mr. W. F. China, of the British Museum (Natural History), discusses the occurrence of large numbers of a very small capsid on apple trees in a nursery near Chertsey, Surrey. The species Campylomma nicolasi Put. and Reut. is an inhabitant of the Mediterranean region and its appearance in Surrey in large numbers is of special interest. The genus Campylomma contains ten palæarctic species but none has previously been found in Britain. It seems unlikely that the species $C$. nicolasi is an indigenous insoct, since it could scarcely have been overlooked in so well-worked a county as Surrey. Mr. China is of opinion that it is more likely to have been introduced with some Mediterranean plant, since the eggs of the family Capsida are almost invariably inserted into plant tissues. Whether a southern insoct of this kind will survive the English climate seems questionable : the description and figure given by him will enable. it to be identified should it be found again in subsequent years.

\section{South London Entomological and Natural History Society}

The Proceedings of the South London Entomological and Natural History Society for 1931-32 forms the record of its sixteenth year of existence and contains several articles of interest to students of insects. Mention may be made of the contribution of $\mathrm{Mr}$. A. E. Tonge, dealing with the charescters of the eggs of British noctuid moths. The eggs of a large number of the species have been examined by him and briefly described and a proportion of them figured in four excellent photographic plates. Dr. E. A. Cockayne describes the larva of I)ysstroma concinnata, and $\mathrm{Mr}$. C. N. Hawkins discusses the pupæ in that genus. Among other articles, Mrs. K. Grant's account of aquatic Hymenoptera and $\mathrm{Mr} \mathrm{H}$. J. Turner's discussion on the classification of the British plume moths are also noteworthy. The volume is well produced and fully indexed, and may be obtained at the Society's rooms in Hibernia Chambers, London Bridge, S.H., price 12s. $6 d$.

\section{Congress of Polish Physicists}

THE sixth Congress of Polish Physicists was held in Warsaw on September 29-October 1, under the presidency of Prof. Ladislas Natanson, professor in the Jagellonian University, Cracow. The president, in his introductory address, spoke on "James Clerk Maxwell's Childhood and Boyhood". The principal subjects chosen for discussion included: the fortunes and misfortunes of physical theorios, the polarisation of dielectrics, the physical interpretation of quantum mechanics, problems of nuclear physics, the con- noxion of physical science with onginecring, genoral relativity, theory of band spectra, teaching of physics, etc., the chief contributors being Profs. Rubinowicz, Zakrzewski, Bialobrzeski, Wertenstein, Wolfke, Weyssonhoff, Patkowski, and others. Prof. Malarski, of Lwow (Leopol), dealt with "Maryan Smoluchowski's Life and Work". More than 120 miscellaneous papers were also presented. The Congress was decidedly successful, about three hundred members taking part in the proceedings. The next Congress will be held in Cracow in 1934.

\section{Engineers' German Circle}

The Engineers' German Circle (Deutscher Ingenieurzirkel in London) was formed in 1931, with the joint support of the Institution of Mechanical Engineers, London, and of the Verein deutscher Ingenieure, Berlin, to further the study of technical German, to give opportunities of hearing lectures in German by eminent German-speaking technical men, and to bring together engineers interested in Continental technical developments. Meetings are held at the Institution of Mechanical kngineers about onco every four weeks during the sessions, on Mondays at 6 P.M. Members meet for tea and social intercourse from 5.15 P.M. Lectures are, so far as possible, illustrated with lantern slides, in order to help members to understand better the technical terms involved; and as a rule, they last about forty minutes, which allows time for a short discussion in German to follow. The lecturers are asked to use simple language and to speak slowly for the benefit of those not very familiar with German. The present session opened on Oct. 10. The subscription to the Circle is 5s. a year, and the Secretary is Mr. H. P. Spratt, Science Museum, London, S.W.7.

\section{Researches in Wood Preservation}

IN addition to some useful notes on timber-treating plants in the British Isles, and on the preservation of timber investigations being carried out at research institutes and forest products laboratories, vol. 2 of the Journal of the British Wood Preserving Association includes some interesting papers read before meetings of the Association during the year, accom. panied by valuable discussions both from the point of view of the oxpert and the practical commercial man. Amongst these are "The Structure of Wood", by L. Chalk ; "Recent Developments in Wood Preservation", by H. Fergusson ; and a general discussion on the fire-proofing of timber. Other interesting material was afforded by the papors on "The Preservation of Mining Timber on the Witwatersrand", by H. A. Read; "Fxperiments on Wood Preservation in the Sea", by J. H. Orton; and "Wood Structure and Penetration of Preservatives", by F. J. Popham. In an editorial note it is stated that the steady growth of the Association continues. The exhibits at agricultural shows and the lectures given by the Secretary to the various clubs and scientific associations in many parts of the country bring the merits of scientific wood preservation before a large public. Inquiries from abroad have increased, particularly from the Colonies,

No. 3286, VoL. 130] 
and the Secretary is now in diroct touch with a large number of timber users and research workers throughout the world.

\section{Psychology of Delinquency}

"Studies In the Psychology of Delinguency", by Grace W. Pailthorpe (Medical Research Council, Special Report Series. No. 170), represents the result of five years work on the psychology of inmates of prisons and of proventive and rescue homes. The investigation aims at finding out what troatment would lead to a restoration of theso peoplo to the ranks of the normal. It is necessary to note that a criminal is not necessarily quite different from other people; he has been found out. Dr. Pailthorpo gives details of an investigation of 200 subjects, 100 in prisons and 100 in homes. The subjects were tested for intelligence, and classified accordingly, as normal, sub-normal, and defective. The prison group proved to have a higher proportion of normals. It is not infrequently asserted that prison people are defective in intelligence: some certainly are, but some are not. They were also interviewed, and classified according to their emotional attitudes. This part of the report is excellent and the detailed case histories are very valuable. It seems obvious on reading them that our presont alternatives in dealing with criminals are hopelessly inadequate and wasteful of money as well as of the human material. A large number show clear signs of mental lack of balance, and it should be part of an enlightened society's work to try to find out the cause. Hence the writer makes a plea for a study of the mentality of the criminal as well as of the crime, and discusses various alternative methods of treatment, including segregation, permanent supervision, education and psychotherapy. Many of the prisoners are really mentally sick, and if there were legal recognition of these conditions some murders might be prevented. In an appendix there is an account of some prison systems abroad.

\section{Announcements}

Prof. J. A. Crowther, professor of physics in the University of Reading since 1924, has been elected honorary secretary of the Institute of Physics, in succession to Prof. A. O. Rankine.

Referring to Prof. P. G. H. Boswell's letter in Nature of August 13 on the subject of the age of the Oldoway skeleton, Dr. L. S. B. Leakey writes to say that he is returning to England at the end of December, and hopes then to be able to place the wholo evidence against Prof. Boswell's conclusions before scientific investigators.

THE first Hinchley Memorial Lecture of the Institution of Chemical Fingineers will be delivered at the Institution of Civil Engineers, Great George Street, Westminstor, S.W.1, by Mr. H. T. Tizard, on October 28, at 6.30 P.M. The subject of Mr. Tizard's lecturo will be "Chemical Engineering and the Aircraft Industry".

No. 3286, Vol. 130]
Tre Lord President of the Council has appointed Prof. A. Fowler and Sir Clement Hindley to be members of the Advisory Council to the Committee of the Privy Council for Scientific and Industrial Research in succession to Sir Alfred Ewing and Sir David Milne-Watson, who have retired on completion of their terms of office. The Lord President of tho Council has also appointed Brigadier-General Sir Harold Hartley to be chairman of the Fuel Research Board, and Dr. N. V. Sidgwick to be chairman of the Chemistry Research Board of the Department of Scientific and Industrial Research, in succession to the late Sir Richard Threlfall.

Tre eighth volume (Pt. 2, Science Section) of the Allahabad Univ. Studies (1932) contains half a dozen papers from the Department of Zoology, five from that of Chemistry and one each from the Depart. monts of Botany and Physics. In the first group it is natural that the work of the head of the department (Prof. Bhattacharya) should bo reflected in the investigations of his pupils and two of the papers are on the Golgi bodies and other cytoplasmic structures in the eggs of Indian snakes and of the crab, Scylla serrata. Other papers record the congenital absence of limbs in tortoises, the structure of the gonad in a hen-feathered cock, and a number of now species of trematodes. Of the chemical papors, that on the formation of inorganic jollies may be noted.

Messrs. Negretti and Zambra have placed on the market a portable sampling hygrometer adapted for the measurement of the hygrometric conditions inside bundles of fabric, wool, fibres, etc. The instrument is of the hair hygrometer type fitted with a tube through which a sample of air is withdrawn from the bundle and circulated through the hygrometer case, which is completely air-tight except for the inlet and outlet air connexions.

Applications are invited for the following appointments, on or before tho dates mentioned :--A research student in the Institute of Pathology and Research at St. Mary's Hospital, Paddington, W.2-The Secretary (Oct. 24). An assistant lecturer in mathematies at the Technical College, Cardiff-The Diroctor of Education, City Hall, Cardiff (Oct. 29). A junior lecturer in the Department of Pathology at the University of Liverpool-The Registrar (Oct. 31). An assistant lands officer in the Works and Juildings Directorate of the Air Ministry-The Secretary (S.2), Air Ministry, Adastral House, Kingsway, W.C.2 (Nov. 1). An assistant lecturer in metallurgy at the Cniversity of Leeds-Tho Registrar (Nov. 7). A part-time instructor of economics and economic history at the Kingston-upon-Thames Technical College-The Principal. A teacher of elementary science, including biology, and a mistress to. teach geography, at the Medway Technical College, Day Technical School for Girls, Chatham-The District Education Officer, 15, New Road Avenue, Chatham. A valve physicist and designer at the Murphy Radio Laboratories, Welwyn Garden City, Herts. 